\title{
Phenology, thermal requirements and maturation of the SR 0.501-17 white wine grape hybrid cultivated in contrasting climatic conditions
}

\author{
Mário José Pedro Júnior ${ }^{*}$ (D), Mara Fernandes Moura², José Luiz Hernandes ${ }^{2}$ \\ 10.1590/0034-737X202067040001
}

\begin{abstract}
The SR 0.501-17 grape hybrid developed for wine making purposes, is characterized for producing white and small berries with seeds. The purpose of this study was to characterize the phenology, thermal requirements and must physicochemical characteristics of the hybrid, in contrasting climatic conditions due to altitude at Jundiaí $(715 \mathrm{~m})$ and Votuporanga ( $483 \mathrm{~m}$ ) respectively located at east and northwest of the São Paulo State-Brazil. Evaluations were performed from 2012 to 2016 and observations during the vine growth period and data of phenology and must soluble solids content and acidity measurements at harvest were taken. Average duration of the pruning-harvest period was 146 and 131 days and grape maturation period was 29 and 27 days, respectively for Jundiaí and Votuporanga. Thermal requirement expressed in degree days for the hybrid growth cycle was 1663 and 1923, respectively for Jundiaí and Votuporanga. Rainfall during the maturation period showed negative correlation with total soluble solids and maturation index and positive correlation with titratable acidity. The effect of temperature on vine growth cycle were more pronounced in Jundiaí in comparison to Votuporanga while the effect of rainfall on the maturation characteristics were more effective in Votuporanga when compared to Jundiaí.
\end{abstract}

Keywords: degree days; soluble solids; titratable acidity.

\section{INTRODUCTION}

Grape growers are increasing the demand for different grape cultivars aiming at elaborating high quality wine due to agrotourism expansion and the possibility of producing white grape wines has been emerging in the State of São Paulo to meet the consumer needs. But, in the climatic conditions of Brazilian south and southwest grape growing regions, high rainfall rates occur during the maturation period, and sugar berry accumulation may be impaired (Mota et al., 2010; Regina et al., 2011; Favero et al., 2011; Dias et al., 2017).

According to Regina et al. (2010) this rainy condition allows a better balance between grape sugars and acids, a factor that benefits the production of white wines, as evaluated by sensorial analysis. In addition, Tonietto $e t$ al. (2006) reported that humid climate favors obtaining suitable grapes for white and sparkling wines elaboration once they show levels of acidity that valorize the product.

However, these climatic conditions promote increase of disease occurrence and grape hybrids arise as a solution for sustainable viticulture regions (Lloreda, 2018). Winegrowers in different regions of the country have already used some white hybrid grapes. Among the hybrids obtained by the Instituto Agronômico (IAC) stand out: 'Rainha'. This hybrid is cultivated on a small scale in the State of São Paulo and when introduced in Santa Catarina it was among the hybrids destined to the elaboration of white wines, with grapes considered of high quality. 'Madalena' a hybrid with muscat flavor and used for sparkling wines (Sousa \& Martins, 2002) shows in the grape

\footnotetext{
Submitted on August $13^{\text {th }}, 2019$ and accepted on June $08^{\text {th }}, 2020$.

${ }^{1}$ Instituto Agronômico de Campinas, Centro de Solos e Recursos Ambientais, Campinas, São Paulo, Brazil. mariopedrojunior@gmail.com

${ }^{2}$ Instituto Agronômico de Campinas, Centro de Frutas, Jundiaí, São Paulo, Brazil. mouram@iac.sp.gov.br; jlhernandes@iac.sp.gov.br

*Corresponding author: mariopedrojunior@gmail.com
} 
growing region of Jundiaí-SP soluble solids content around $16^{\circ}$ Brix (Hernandes et al., 2010). 'Moscatel de Jundiaí' used for white liqueur wines can also be consumed as table grapes (Sousa \& Martins, 2002) show sugar content between 16 and $18^{\circ}$ Brix during the summer growing season (Hernandes et al., 2010).

Embrapa also provided to grape growers white grape hybrids like the 'BRS Lorena' and 'Moscato Embrapa'. 'BRS Lorena has been cultivated in the southern region of the country, as well as in tropical regions (Camargo, Maia \& Ritschel, 2010) and eastern of São Paulo State (Pedro Júnior et al., 2013) showing must physicochemical characteristics compatible for white wines.

In spite of the existence of different white grape hybrids for wine purposes, the demand for new hybrids promoted the evaluation and selection of genetic crosses, in the IAC grape-breeding program, which need agronomic characterization in different climatic conditions, as well as the evaluation of its winemaking performance. Thus, the selection made at the IAC highlighted the hybrid 'SR 0.50117 ' for the winemaking purposes, due to cluster quality, vine rusticity and sugar accumulation characteristics. This hybrid, developed at the former Experimental Station of São Roque (São Paulo, Brazil), is a white grape, with small round seeded berries and medium maturity cycle.

When a grape cultivar is introduced in a new growing region, the knowledge of phenology plays a major role in the success of the production system since the characterization of the phenological stages duration and thermal requirements of the vines in different climatic regions provide information for management (BertolettiBarros et al., 2015). Also allows the cropping system planning in similar climatic conditions aiming at determining the harvesting season (Nunes et al., 2016).

Among the several factors that may influence grapevine phenology and maturation process, stands out the genetics of cultivar and the region of production. It has been reported the influence of the air temperature on duration of different phenological stages and reproductive vine cycle (Parker et al., 2011; Santibáñez et al., 2014). In addition, the occurrence of low temperatures and high rainfall rates during the maturation period may be detrimental to berry sugar accumulation (Mota et al., 2010; Favero et al. 2011).

Protas, Camargo \& Mello (2006) reported that viticulture activities are traditional in temperate climate regions, and at the eastern region of the State of São Paulo, is found with altitudes varying between 700 and $900 \mathrm{~m}$, annual rainfall of $1400 \mathrm{~mm}$ and temperature of $19.5^{\circ} \mathrm{C}$, where the altitude compensates the effect of latitude. Currently the northwest region of the state emerges as a pole of tropical viticulture, where altitudes range from 450 to $550 \mathrm{~m}$, total annual rainfall of $1300 \mathrm{~mm}$ and the average temperature of $23^{\circ} \mathrm{C}$.
These climatic differences between the east and northwest region may influence both phenology and maturation process of grape cultivars. Therefore, the objective of this study was to evaluate and compare the performance of SR 0.501-17 white grape hybrid in contrasting climatic conditions, represented by municipalities of the eastern and northwestern regions of the state of São Paulo, aiming at characterizing the different phenological stages duration; thermal requirements and the influence of temperature and rain occurrence on must physicochemical characteristics.

\section{MATERIAL AND METHODS}

The evaluation of the phenological and maturation performance of the SR 0.501-17 white grape hybrid, in contrasting climates, was done in experimental vineyards with $240 \mathrm{~m}^{2}$ of the Centro de Frutas, located in Jundiaí-SP (Latitude: $23^{\circ} 12^{\prime} \mathrm{S}$; Longitude: $46^{\circ} 53^{\prime} \mathrm{W}$; Altitude: $715 \mathrm{~m}$ ), and $300 \mathrm{~m}^{2}$ of the Centro de Seringueira e Recursos Agroflorestais, in Votuporanga-SP (Latitude: $20^{\circ} 15^{\prime}$ 'S; Longitude: 500' W; Altitude: $483 \mathrm{~m}$ ) of the Instituto Agronômico de Campinas from Agência Paulista de Tecnologia do Agronegócio - Secretaria de Agricultura e Abastecimento (IAC/APTA/SAA). The climate according to Koeppen is classified as Aw in Votuporanga and $\mathrm{Cfb}$ in the region of Jundiaí. The vines were grafted on the IAC 766 'Campinas' rootstock and trained on vertical shoot position trellis with three wires to support the shoots. The spacing was $2 \times 1 \mathrm{~m}$ and $2 \times 1.5 \mathrm{~m}$, respectively in Jundiaí and Votuporanga. Grapevine irrigation from budburst to beginning of maturation was performed, when necessary, with micro sprinkler system, as described by Conceição et al. (2017) to avoid water deficit.

In each experimental area, the evaluations were taken during the grape growing seasons from 2012 to 2016 and for maintenance of the experiments were adopted cultivation techniques recommended for the grape growers of each region. The planting of the rootstocks was carried out in November 2008 and the grafting in June 2009. Short pruning, leaving two buds per shoot, was carried out during July in Votuporanga and early August in Jundiaí. Harvest occurred during early December in Votuporanga and late December in Jundiaí. Dormex ${ }^{\circledR}$ at $3.5 \%$ was used to stimulate budburst.

At harvest, when the $\mathrm{pH}$ of the must reached values between 3.3 and 3.5, 100 berries were randomly harvested in the vineyard and subdivided into four samples of 25 berries each. The berries were manually smashed and the must used to determine soluble solids (SS) content ( ${ }^{\circ}$ Brix) with digital refratometer (Atago Pal-3) and titratable acidity (TA) using a semi-automatic pHmeter - Digimed DM-22 $(0.1 \mathrm{~N} \mathrm{NaOH}$ solution and titration endpoint $\mathrm{pH}=8.2)$ and 
the result being expressed as $\mathrm{mEqL}^{-1}$ and $\%$ of tartaric acid (TAc). The maturation index was calculated by the ratio between the soluble solids and the tartaric acid content.

Vine phenology was characterized evaluating weekly the grape phenological stages, using the scale developed by Lorenz et al. (1995) to determine the occurrence of budburst, flowering, beginning of maturation (berry softening) and harvesting. The duration, in days, of the phenological stages was determined as follows P-B: Pruning-Budburst; B-F: Budburst-Flowering; F-M: Flowering-Beginning of maturation; $\mathrm{M}-\mathrm{H}$ : Beginning of maturation-Harvest.

Maximum and minimum temperatures and rainfall data were collected in automatic standard weather stations, managed by CIIAGRO (IAC/APTA/SAA), at the experimental sites. The calculation of the thermal requirements was done through the accumulation of growing degree days (GDD) obtained by the averages between the maximum and minimum temperatures, subtracting the base temperature, considered as $10^{\circ} \mathrm{C}$ (Sato et al., 2011; Radünz et al., 2015).

The relation between the values of cycle duration and air temperature was done by linear regression analysis using the least square method while the comparison between must physicochemical characteristics and total rainfall in the maturation period was evaluated by the correlation coefficient. The comparison of mean values of the physicochemical characteristics of the grapes in the different localities was done, as suggested by Silvestre (2016) using the "U" test of Mann-Whitney at 5\% probability level.

\section{RESULTS AND DISCUSSION}

Average air temperature and total rainfall values obtained during the vine growth cycle (Pruning-Harvest) and grape maturation period (Beginning of MaturationHarvest), for the evaluated growing seasons, in Jundiaí and Votuporanga, are shown in Table 1.

During the grapevine growth cycle, temperature, on average, was $3.3^{\circ} \mathrm{C}$ higher in Votuporanga when compared to Jundiaí, while the total rainfall was $164 \mathrm{~mm}$ lower. Taking in consideration the maturation period of the grapes, it was verified that temperature was, on average, $2,7^{\circ} \mathrm{C}$ higher in Votuporanga, whereas for rainfall, although being 30 mm less than in Jundiaí, no difference was observed comparing the localities. The growing seasons with less occurrence of rainfall in Votuporanga were 2014 and 2016, while in Jundiaí were 2013 and 2014. The occurrence of lower rainfall levels during the maturation period usually enhances berry grape sugar accumulation, favoring obtainment of high quality product for wine making purposes.

\section{Phenological subperiod duration and air temperature relationship}

The duration of different phenological subperiods and mean air temperature for the SR.0.501-17 grape hybrid cultivated under the contrasting climatic conditions of Jundiaí and Votuporanga during the growing seasons from 2012 to 2016 are shown in Figure 1.

The Pruning-Budburst phenological stage had an average duration of 16 days in both Jundiaí and Votuporanga, varying from 12 to 20 days depending on the growing season. The Budburst-Flowering stage was longer in Jundiaí (35 days) when compared to Votuporanga (31 days). Also for the Flowering-Beginning of maturation subperiod, it was observed a longer duration in Jundiaí, being the average values 66 and 57 days, respectively, for Jundiaí and Votuporanga. The maturation period of the grapes, represented by the duration of the phenological subperiod: Beginning of maturation (berry softening) Harvest, was similar in both localities evaluated varying between 27 and 29 days.

The obtained values of the duration of the maturation period for SR.0.501-17 was similar to that reported by Hernandes et al. (2010) for 'Moscatel de Jundiaí' and 'Madalena'. Both are white grape cultivars for wine purposes that, when grown in the region of Jundiaí, showed a duration of the phenological stage of the 30 days. In addition, for 'Cabernet Sauvignon' was reported a duration of maturation period of 33 days, in the subtropical northwest region of Paraná (Roberto et al., 2005). On the other hand, the duration of the maturation period for SR.0.501-17 was lower than the values reported by Pedro Júnior et al. (2013) for 'BRS Lorena' grape grown in São Roque-SP, which averaged 57 days. It was also lower than the results obtained by Brighenti et al. (2014) for the cultivars Chardonnay and Sauvignon Blanc grown in São Joaquim-SC. The obtained values were respectively, 44 and 41 days and for the cultivars Proseco, Vermentino and Verdichio whose duration of the maturation varied between 53 and 62 days, probably due to the regional climatic condition, due to existing low temperatures as a function of high altitude, and the genetic characteristics of the cultivar. The characteristic of having a short maturation period demonstrated by SR.0.501-17 is of high concernment for the grape growers because it allows two crop cycles in one producing year (Moura et al., 2017).

Regarding the vine growth cycle duration (PruningHarvest), it was found to be about 15 days longer in Jundiaí when compared to Votuporanga, being the observed average values 146 days for Jundiaí and 131 days for Votuporanga. Cultivars of grapes for high quality wine, such as the 'Sauvignon Blanc' grown in the Cam- 
panha region of the Rio Grande do Sul state, also had a similar cycle duration, that is, 147 days (Radünz et al., 2015). While Brighenti et al. (2014) evaluating Italian autochthonous varieties reported for São Joaquim, in Santa Catarina state, cycle durations ranging from 217 to 246 days as a function of the cultivar and low temperatures in the region.

In Figure 1 is shown the influence of the average air temperature on vine growth cycle duration. For the 2013 growing season, lower temperatures were observed in Votuporanga and the growth cycle duration was longer, with 137 days. While in the growing season of 2015 when higher temperatures occurred, the cycle was shortened and it was obtained, respectively, for Jundiaí and Votuporanga, 136 and 126 days.

The effect of air temperature on the SR 0.501-17 cycle duration is shown in Figure 2 by means of regression analysis used to verify the relationship between cycle duration and air temperature.

The obtained regression coefficients were 0.84 and 0.76 , respectively for Jundiaí and Votuporanga. The angular coefficient of the regression equation for Jundiaí was -10.29 indicating a more pronounced effect of temperature in the cycle length compared to Votuporanga, whose angular coefficient was -4.9. That can be interpreted as, for each degree of temperature rise in Jundiaí the cycle shortens in approximately 10 days, while in Votuporanga it diminishes 5 days on average. The high temperatures observed in Votuporanga for all the growing seasons allow verifying graphically the effect in shortening vine cycle duration when compared to Jundiaí.

\section{Thermal requirements}

The thermal requirements, expressed in terms of accumulated degree days, considering the base temperature of $10{ }^{\circ} \mathrm{C}$, are shown in Table 2 for different growing seasons and phenological subperiods of SR 0.50117 in the evaluated localities.

The thermal requirement for the subperiod: PruningBudburst was, on average, 129 and 168 GDD, respectively for Jundiaí and Votuporanga, while for the BudburstFlowering subperiod was, respectively 342 and 400 GDD.

During the vine vegetative development, represented by the subperiod: Flowering-Beginning of maturation, it was required 791 and 870 GDD, respectively for the localities of Jundiaí and Votuporanga. For grape maturation, characterized by the subperiod: Beginning of maturationHarvest, it was required 390 and 485 GDD for Jundiaí and Votuporanga. The thermal requirement for the vine growth cycle observed, considering: Pruning to Harvest, was 1653 and 1923 GDD, respectively for Jundiaí and Votuporanga. Table 2 shows that standard deviation for the cycle duration in Jundiaí was 12.1 GDD, while in Votuporanga it was 28.4 GDD. These values, considering the average temperatures of the different evaluated localities, represent a variation on cycle duration of about 1 day for Jundiaí and 2 days for Votuporanga.

In Votuporanga and Jundiaí different thermal requirement values were observed for the hybrid SR 0.50117 to complete the growth cycle. The difference between obtained values of thermal requirement found when comparing different localities was reported by Santibáñez et al. (2014) associating this variation to the effect of climatic

Table 1: Temperature and rainfall during the grapevine cycle and maturation period of the white grape hybrid SR 0.501-17 grown in Jundiaí and Votuporanga counties, São Paulo State, Brazil, during the growing seasons from 2012 to 2016

\begin{tabular}{|c|c|c|c|c|c|}
\hline \multirow{2}{*}{ Locality } & \multirow{2}{*}{ Growing season } & \multicolumn{2}{|c|}{ Grapevine cycle } & \multicolumn{2}{|c|}{ Maturation period } \\
\hline & & Temperature $\left({ }^{\circ} \mathrm{C}\right)$ & Rainfall (mm) & Temperature $\left({ }^{\circ} \mathbf{C}\right)$ & Rainfall (mm) \\
\hline \multirow{7}{*}{ Jundiaí } & 2012 & 21.6 & 501 & 24.2 & 200 \\
\hline & 2013 & 20.6 & 407 & 23.7 & 100 \\
\hline & 2014 & 21.3 & 312 & 23.0 & 118 \\
\hline & 2015 & 22.1 & 342 & 24.1 & 245 \\
\hline & 2016 & 21.0 & 545 & 23.2 & 166 \\
\hline & Mean & $21.3 b$ & $481 \mathrm{a}$ & $23.6 b$ & $166 \mathrm{a}$ \\
\hline & $\mathrm{SD}$ & 0.57 & 127 & 0.51 & 59 \\
\hline \multirow{7}{*}{ Votuporanga } & 2012 & 24.7 & 253 & 27.7 & 158 \\
\hline & 2013 & 23.5 & 301 & 26.2 & 151 \\
\hline & 2014 & 24.6 & 312 & 25.9 & 115 \\
\hline & 2015 & 25.6 & 370 & 26.0 & 159 \\
\hline & 2016 & 24.4 & 351 & 25.9 & 98 \\
\hline & Mean & $24.6 \mathrm{a}$ & $317 b$ & $26.3 \mathrm{a}$ & $136 \mathrm{a}$ \\
\hline & $\mathrm{SD}$ & 0.75 & 46 & 0.77 & 28 \\
\hline
\end{tabular}

SD: Standard Deviation. Means followed by the same letter, in the comparison of variables between localities in the same phenological stage, do not differ statistically by the Mann-Whitney ' $U$ ' test at $5 \%$ of probability. Grapevine cycle: Pruning to Harvest; Maturation period: Beginning of maturation to Harvest.

Rev. Ceres, Viçosa, v. 67, n.4, p. 247-255, jul/aug, 2020 
variables such as temperature and high atmospheric demand causing the closure of stomata around midday. Another factor that occurs in Votuporanga, besides allowing faster accumulation of growing degree days due to elevated temperatures, is the high evapotranspiration rate that could submit the plants to periods of water stress interfering in the duration of the phenological subperiods and consequently accumulation of degree days (Massignam \& Angelocci, 1993).

Chavarria et al. (2009) obtained an average thermal requirement value of 1750 GDD for 'Moscato Giallo' grapevines grown in Flores da Cunha-RS region. Ricce $e t$ al. (2013) observed thermal requirement values similar to that obtained for SR 0.501-17 in Jundiai for the cultivars Moscato Embrapa, Moscato Giallo and Trebbiano in the state of Paraná.

\section{Must physicochemical characteristics and rain at maturation period}

Table 3 shows the mean values of must physicochemical characteristics of SR 0.501-17 and Figure 3 the relationship between soluble solids (SS) content, total titratable acidity (TA) and maturation index (MI) and total rainfall during the grape maturation period.
For both localities, Jundiaí and Votuporanga, it was observed a variation in SS values for the different growing seasons, probably related to rainfall observed during the maturation period of the grapes, since there is a decreasing effect on berry sugar content related to rainfall occurrence. Santos et al. (2010) also reported that it is usually expected variations on must physicochemical characteristics when comparing growing seasons, once they are influenced by the climatic conditions, mainly rainfall occurrence.

The observed SS values in Jundiaí varied from 16.8 to $20.5^{\circ}$ Brix for the different growing seasons (Table 3 ). These values were higher than reported by Hernandes et al. (2010) for hybrid grapes ('Moscatel de Jundiaí' and 'Madalena') whose SS values averaged $16.7^{\circ}$ Brix. Pedro Júnior et al. (2013) obtained similar values of soluble solids content (18.7 to $20.3^{\circ}$ Brix) for 'BRS Lorena' grapevine in the winegrowing region of São Roque (SP).

In Votuporanga, SS values variation for different growing seasons was also observed, ranging from 16.6 to $20.5^{\circ}$ Brix (Table 3). This difference in SS values, as in Jundiaí, was probably due to the occurrence of rain during grape maturation. Obtained average SS values were $18.2^{\circ}$ Brix and $18.9^{\circ}$ Brix, respectively in Votuporanga and Jundiaí. Although the observed rainfall amounts during the grape
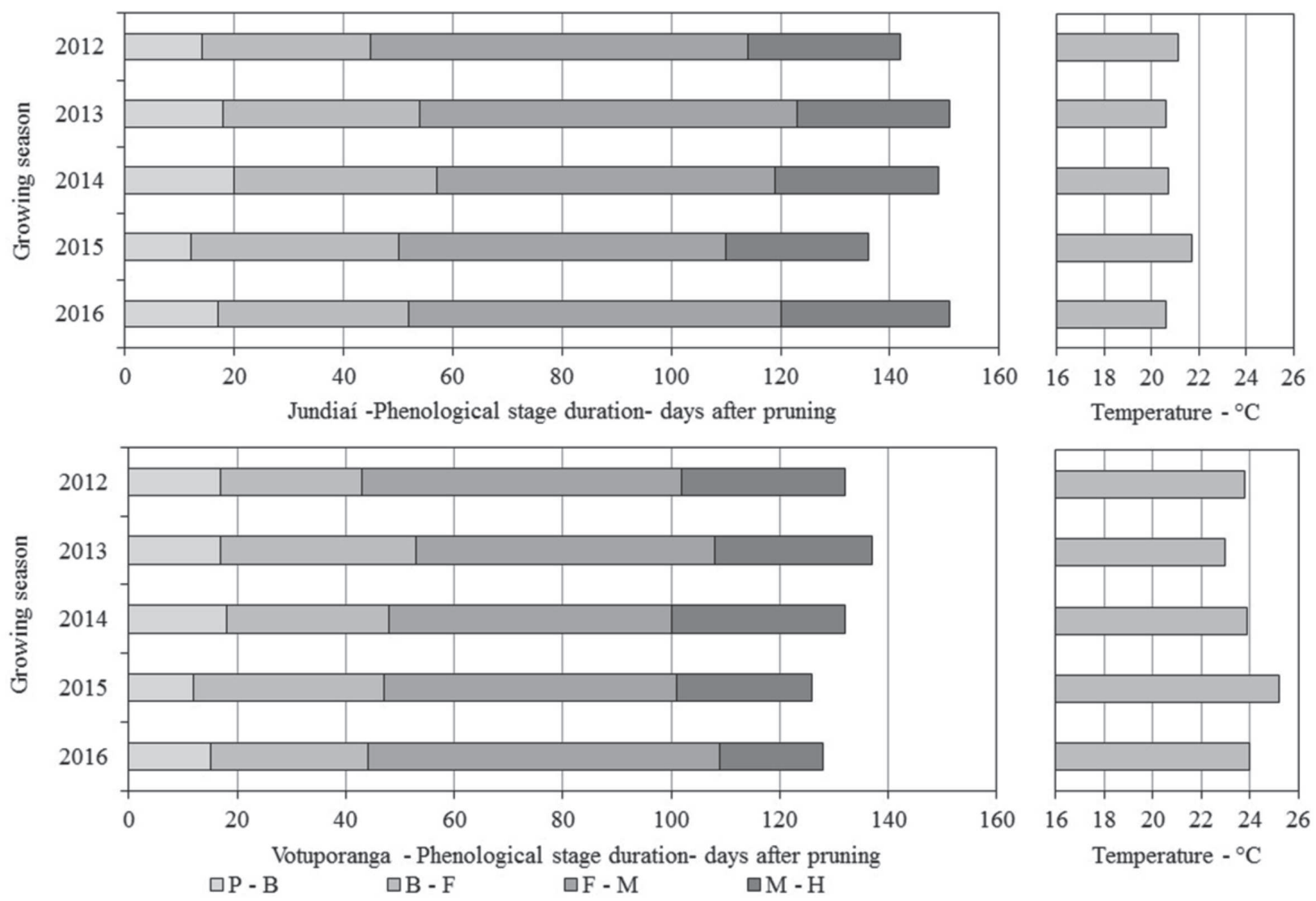

Figure 1: Phenological subperiods duration of the white grape hybrid SR 0.501-17 and average temperature for different growing seasons at Jundiaí and Votuporanga counties, São Paulo State, Brazil. P-B: Pruning-Budburst; B-F: Budburst-Flowering; F-M: Flowering-Beginning of maturation (veraison); M-H: Beginning of maturation-Harvest. 
ripening period were lower in Votuporanga compared to Jundiaí, no influence was observed on the average value of SS considering all evaluated growing seasons, and no statistical difference between localities was found for total rainfall during grape maturation (Table 1).

The occurrence of rainfall during maturation has been evaluated as detrimental to sugar accumulation in grapes and in this experiment, high SS values were observed, for the growing seasons with low rainfall occurrence during the maturation period. In Jundiaí lower rates of rainfall occurred during 2013 and 2014 and in
Votuporanga during 2014 and 2016 (Table 1), being SS above $18.5^{\circ}$ Brix (Table 3 ). For the growing seasons of 2012 and 2015, when rainfall occurrence was high during grape maturation period for both localities, low values soluble solids were observed.

The correlation (Figure 3) between the soluble solids content and rain accumulated during grape maturation period was negative, indicating that high rainfall amounts influence the dilution of berry soluble solids. The obtained correlation coefficients values were 0.76 and 0.77 , respectively, for the Votuporanga and Jundiaí. Araújo et

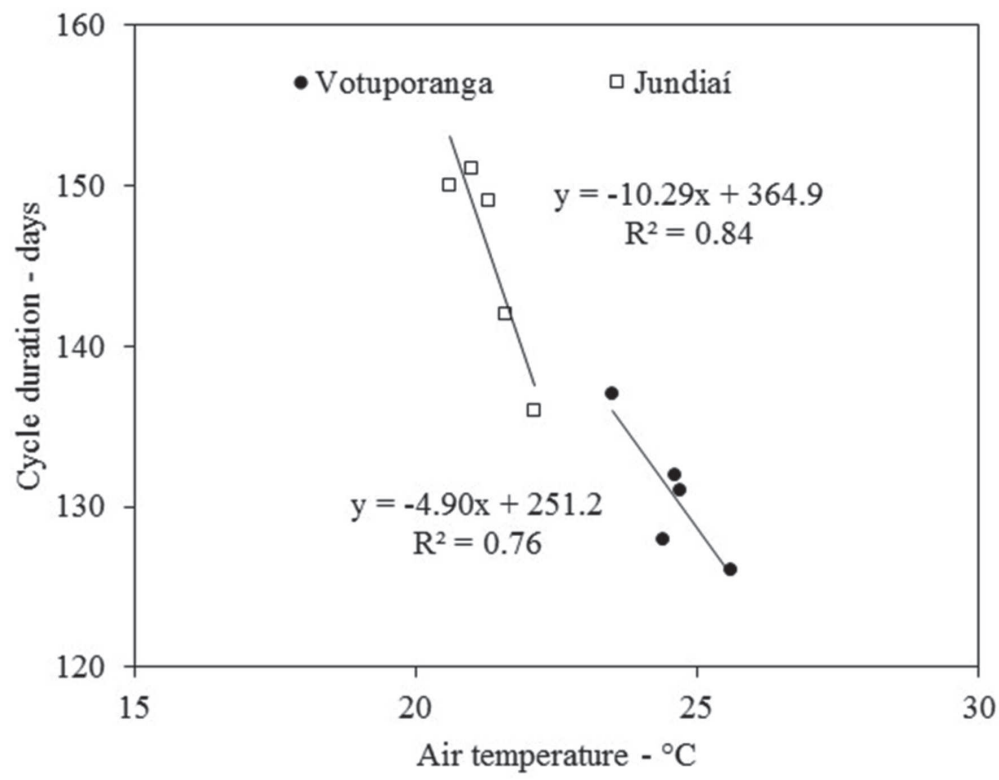

Figure 2: Relation between cycle (y) duration (pruning to harvest) of the white grape hybrid SR 0.501-17 and mean air temperature (x) for Jundiaí and Votuporanga counties, São Paulo State, Brazil.

Table 2: Thermal requirements (growing degree days) for different phenological subperiods of the white grape hybrid SR 0.501-17 cultivated in Jundiaí and Votuporanga counties, São Paulo State, Brazil during the growing seasons from 2012 to 2016

\begin{tabular}{lcccccc}
\hline \multirow{2}{*}{ Locality } & Growing & \multicolumn{3}{c}{ Phenological subperiod } \\
\cline { 3 - 7 } & season & P - B & B - F & F - M & M - C & P - H \\
\hline \multirow{4}{*}{ Jundiaí } & 2012 & 113 & 318 & 824 & 396 & 1651 \\
& 2013 & 131 & 331 & 756 & 395 & 1613 \\
& 2014 & 148 & 362 & 786 & 391 & 1687 \\
& 2015 & 116 & 369 & 804 & 364 & 1653 \\
& 2016 & 137 & 332 & 784 & 407 & 1660 \\
\hline \multirow{4}{*}{ Votuporanga } & 129 & 342 & 791 & 391 & 1653 \\
& Mean & 14,0 & 20,3 & 14,5 & 16,0 & 12,1 \\
\hline & 2012 & 140 & 357 & 907 & 532 & 1936 \\
& 2013 & 151 & 417 & 815 & 469 & 1852 \\
& 2014 & 181 & 405 & 837 & 509 & 1932 \\
& 2015 & 167 & 474 & 932 & 399 & 1972 \\
& Mean & 201 & 346 & 860 & 514 & 1923 \\
\hline SD & 168 & 400 & 870 & 485 & 1923 \\
\end{tabular}

P-B: Pruning - Budburst; B-F: Budburst - Flowering; F-M: Flowering- Beginning of maturation; M-C: Beginning of maturation - Harvest; P-C: Pruning - Harvest; SD: Standard Deviation

Rev. Ceres, Viçosa, v. 67, n.4, p. 247-255, jul/aug, 2020 
al. (2016) also verified that rainfall, occurring 30 days before harvesting, corresponding to the maturation period of the grapes, negatively influenced the soluble solids content of Vitis labrusca cultivars in the grape growing region of Bento Gonçalves and Flores da Cunha in Rio Grande do Sul state.

Regarding total titratable acidity, the obtained mean value was $91 \mathrm{mEqL}^{-1}$ both for Votuporanga and for Jundiaí (Table 3). These values were lower than reported by Pedro Júnior et al. (2013) for the cultivar BRS Lorena cultivated in the region of São Roque-SP and those observed by Silva et al. (2015) for the cultivars Rainha and BRS Lorena cultivated in Jundiaí-SP, which ranged between 110 and $115 \mathrm{mEqL}^{-1}$.

Rainfall occurrence during grape maturation period, in both Jundiaí and Votuporanga, influenced increasing titratable acidity values. In Votuporanga rainfall values of $150 \mathrm{~mm}$ allowed to obtain must with titratable acidity around $110 \mathrm{mEqL}^{-1}$, while in Jundiaí, the values did not exceed 100 $\mathrm{mEqL} \mathrm{L}^{-1}$ even under conditions of high rainfall. According to Felippeto et al. (2016), total acidity levels between 90 and $120 \mathrm{mEqL}^{-1}$ are acceptable for grapes considering winemaking purposes. The correlation coefficient was positive for both localities indicating that the occurrence of rain influences in order to increase grape must titratable acidity.

The values of tartaric acid content, expressed as a percentage, varied between 0.52 and 0.78 , in Votuporanga, and between 0.65 and 0.75 , in Jundiaí (Table 3 ). The average value for the different growing seasons was $0.69 \%$, being the same in both locations, and there was no statistical difference between localities. The obtained value was similar to those reported for 'SR 0.501-17' and 'Madalena' and lower than those obtained for cultivars Moscatel de Jundiaí and BRS Lorena in the region of Jundiaí-SP (Moura et al., 2017).

In general, no difference was found in the evaluated must physicochemical characteristics when comparing Jundiaí and Votuporanga besides the climatic differences between localities. On the other hand, Regina et al. (2010) reported differences on soluble solids and acidity values for 'Chardonnay' and 'Pinot Noir' grown in Minas Gerais state due the effect of altitude. Probably because the difference in altitude for the localities evaluated at Minas Gerias were greater than the difference in the comparison of sites in this experiment.

The maturation index (MI) was 27.6 in Votuporanga and 28.2 in Jundiaí (Table 3) and no difference was found when comparing localities. According to Sato et al. (2009) the MI seems to be an option to determine the ideal grape harvest point because it represents the balance between sugar content and acidity of the must.

In Figure 3, it is possible to verify the negative influence of rainfall on MI, more pronounced in Votuporanga, probably due to the short vine cycle and high temperatures in the region. Similar MI values were reported for the 'BRS Lorena' in the region of São Roque - SP (Pedro Júnior et al., 2013). Still, and according to Rizzon \& Miele (2002) values of MI between 30 and 32 are appropriate for the wine purpose.

Table 3: Soluble solids content (SS), tartaric acid content (TAc), titratable acidity (TA), maturation index (MI) and rainfall during the maturation period for the white grape hybrid SR 0.501-17 grown in Jundiaí and Votuporanga counties, São Paulo State, Brazil, during the growing seasons from 2012 to 2016

\begin{tabular}{|c|c|c|c|c|c|}
\hline \multirow{2}{*}{ Locality } & \multirow{2}{*}{ Growing season } & \multirow{2}{*}{$\begin{array}{c}\text { S S } \\
{ }^{\circ} \text { Brix }\end{array}$} & \multirow{2}{*}{$\begin{array}{c}\text { TAc } \\
\%\end{array}$} & \multirow{2}{*}{$\begin{array}{c}\mathrm{TA} \\
\mathrm{mEq} \mathbf{L}^{-1}\end{array}$} & \multirow{2}{*}{ MI } \\
\hline & & & & & \\
\hline \multirow{7}{*}{ Jundiaí } & 2012 & 18.8 & 0.69 & 93 & 27.1 \\
\hline & 2013 & 20.0 & 0.65 & 90 & 31.0 \\
\hline & 2014 & 20.5 & 0.65 & 86 & 32.2 \\
\hline & 2015 & 16.8 & 0.75 & 101 & 22.4 \\
\hline & 2016 & 18.5 & 0.65 & 87 & 28.5 \\
\hline & Mean & $18.9 \mathrm{a}$ & $0.69 \mathrm{a}$ & $91 \mathrm{a}$ & $28.2 \mathrm{a}$ \\
\hline & $\mathrm{SD}$ & 1.4 & 0.05 & 5.9 & 3.9 \\
\hline \multirow{7}{*}{ Votuporanga } & 2012 & 16.6 & 0.78 & 105 & 21.5 \\
\hline & 2013 & 17.1 & 0.68 & 86 & 26.6 \\
\hline & 2014 & 20.5 & 0.68 & 91 & 30.1 \\
\hline & 2015 & 17.0 & 0.80 & 106 & 21.5 \\
\hline & 2016 & 19.7 & 0.52 & 69 & 38.4 \\
\hline & Mean & $18.2 \mathrm{a}$ & $0.68 \mathrm{a}$ & $91 \mathrm{a}$ & $27.6 \mathrm{a}$ \\
\hline & $\mathrm{SD}$ & 1.8 & 0.11 & 15.2 & 7.0 \\
\hline
\end{tabular}

SD: Standard Deviation. Means followed by the same letter, in the comparison of variables between localities, do not differ by the MannWhitney ' $U$ ' test at $5 \%$ of probability. 

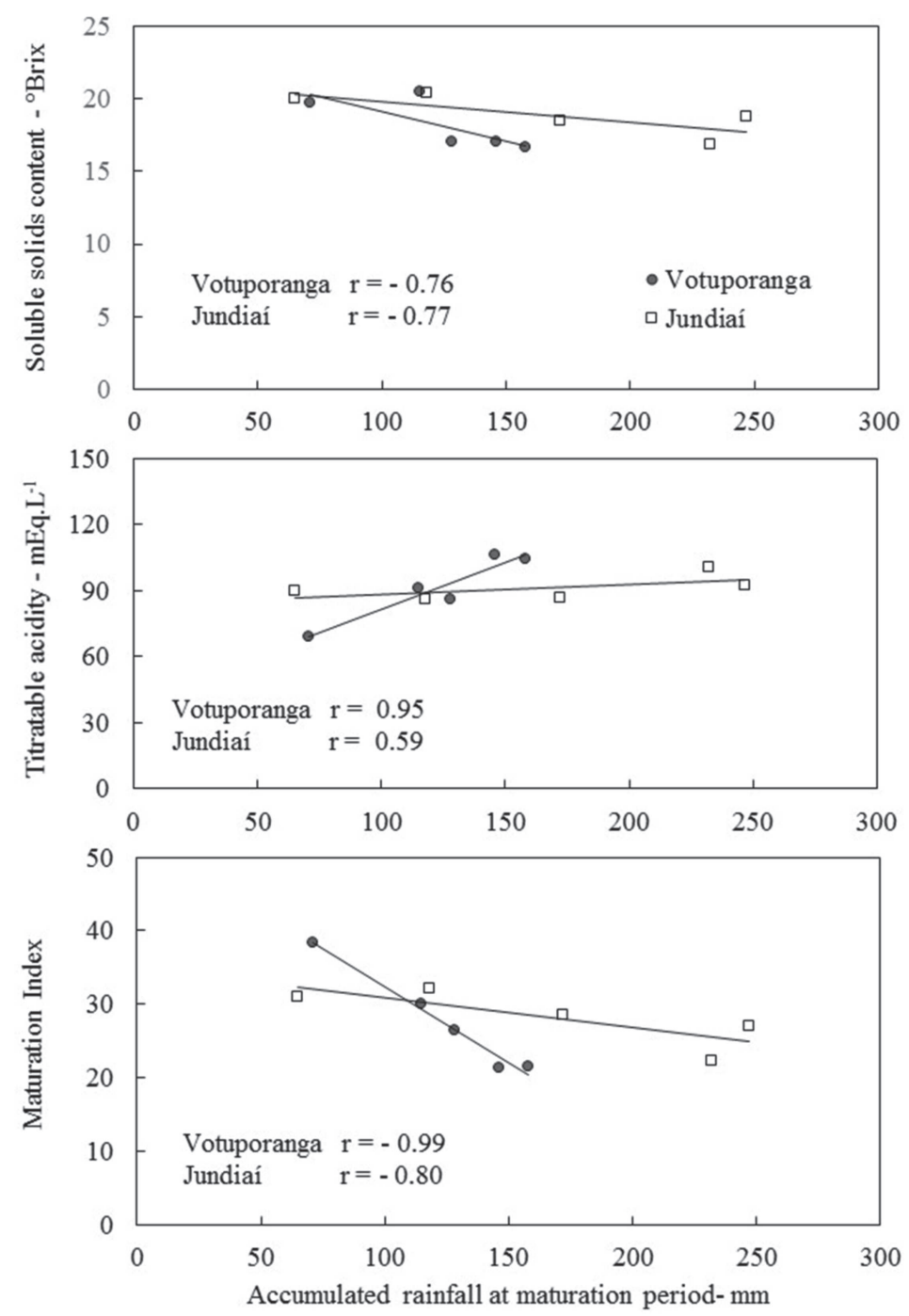

Figure 3: Correlation between must physicochemical characteristics of the white grape hybrid SR 0.501-17 and accumulated rainfall during the maturation period for Jundiaí and Votuporanga counties, São Paulo State, Brazil.

\section{CONCLUSIONS}

The SR 0.501-17 cycle duration is higher in Jundiaí when compared to Votuporanga being respectively, 146 and 131 days. The angular coefficient of the regression lines allowed verifying that in Jundiaí the effect of the air temperature on the cycle duration is more pronounced in comparison to Votuporanga.

The thermal requirement expressed in degree days for the SR 0.501-17 cycle is higher in Votuporanga (1923 GDD) compared to Jundiaí (1653 GDD).

SR 0.501-17 must physicochemical characteristics do not differ when comparing Jundiaí and Votuporanga.

The correlation coefficient between must physicochemical characteristics and rainfall during the maturation period is negative for soluble solids content and maturation index and positive for titratable acidity in both locations.

\section{ACKNOWLEDGEMENTS, FINNANCIAL SUPPORT AND FULL DISCLOSURE}

The authors would like to thank FAPESP (Process: 2012/00292-9 and 2014/22824-8) for the financial support of the experiment and CNPq (Process: 302162/2016-0) for granting productivity research scholarship for the first author. There was no conflict of interests in carrying the research and the paper is available for full disclosure.

\section{REFERENCES}

Araújo CMG, Spada PKWDS, Reis DS, Carnieli GJ \& Dutra SV (2016) Influência climática em mostos e vinhos da safra 2015. Revista Brasileira de Viticultura e Enolologia, 8:66-73.

Bertoletti-Barros L, Margoti G, Fowler JG, May de Mio LL \& Biasi LA (2015) Thermal requirement and phenology of different cultivars of Vitis labrusca on different rootstocks. Semina: Ciências Agrárias, 36:2433-2442. 
Brighenti AF, Silva AL, Brighenti E, Porro D \& Stefanini M (2014) Desempenho vitícola de variedades autóctones italianas em condição de elevada altitude no Sul do Brasil. Pesquisa Agropecuária Brasileira, 49:465-474.

Camargo UA, Maia JDG \& Ritschel P (2010) Embrapa Uva e Vinho: Novas cultivares brasileiras de uva. Bento Gonçalves, Embrapa Uva e Vinho. 64p.

Chavarria G, Santos HP, Mandelli F, Marodin GAB, Bergamaschi H \& Cardoso LS (2009) Caracterização fenológica e requerimento térmico da cultivar Moscato Giallo sob cobertura plástica. Revista Brasileira de Fruticultura, 31:119-126.

Conceição MAF, Tecchio MA, Souza RT, Silva MJR \& Moura MF (2017) Estimativa dos coeficientes de cultivo (kc) de videiras para suco. Agrometeoros, 25:203-210.

Dias FAN, Mota RV, Souza CR, Pimentel RMA, Souza LC, Souza AL \& Regina MA (2017) Rootstock on vine performance and wine quality of 'Syrah' under double pruning management. Scientia Agricola, 74:134-141

Favero AC, Amorim DA, Mota RV, Soares AM, Souza CR \& Regina MA (2011) Double-pruning of 'Syrah' grapevines: a management strategy to harvest wine grapes during the winter in the Brazilian Southeast. Vitis, 50:151-158.

Felippeto J, Alembrandt R \& Ciotta MN (2016) Maturação e composição das uvas Cabernet Sauvignon e Merlot produzidas na região de São Joaquim, SC. Agropecuária Catarinense, 29:74-79.

Hernandes JL, Pedro Júnior MJ, Santos AO \& Tecchio MA (2010) Fenologia e produção de cultivares americanas e híbridas de uvas para vinho, em Jundiaí - SP. Revista Brasileira de Fruticultura, 32:135-142.

Lloreda M F (2018) Use of hybrids in viticulture. A challenge for the OIV. OENO One, 52:231-234.

Lorenz DH, Eichhorn KW, Bleidholder H, Klose R, Meier U \& Weber E (1995) Phenological growth stages of the grapevine (Vitis vinifera L. ssp. vinifera): Codes and descriptions according to the extended BBCH scale. Australian Journal of Grape and Wine Research, 1:100-103.

Massignam AM \& Angelocci LR (1993) Relação entre a temperatura do ar, disponibilidade hídrica no solo, fotoperíodo e duração dos subperíodos fenológicos do girassol. Revista Brasileira de Agrometeorologia, 1:71-79.

Moura MF, Souza JR, Modesto LR, Hernandes JL \& Santos TS (2017) Cycle, productivity and must chemical characteristics of varieties of white wine grape. In: Bio Web of Conferences, 9:01-04.

Mota RV, Silva CPCS, Favero AC, Purgatto E, Shiga TM \& Regina MA (2010) Composição físico-química de uvas para vinho fino em ciclos de verão e inverno. Revista Brasileira de Fruticultura, 32:1127-1137.

Nunes NAS, Leite AV \& Castro CC (2016) Phenology, reproductive biology and growing degree days of the grapevine 'Isabel' (Vitis labrusca, Vitaceae) cultivated in northeastern Brazil. Brazilian Journal of Biology, 76:975-982.

Parker AK, Cortázar-Atauri IG, van Leeuwen C \& Chuine I (2011) General phenological model to characterize the timing of flowering and veraison of Vitis vinifera L. Australian Journal of Grape and Wine Research, 17:206-216.

Pedro Júnior MJ, Hernandes JL, Blain GC \& Bardin-Camparotto L (2013) Produção e qualidade da uva BRS Lorena sustentada em espaldeira em São Roque, SP. Revista Brasileira de Viticultura e Enologia, 5:08-16.
Protas JFS, Camargo UA \& Mello LMR (2006) Viticultura brasileira: regiões tradicionais e pólos emergentes. Informe Agropecuário, 27:07-15.

Radünz AL, Schöffel ER, Borges CT, Malgarim MB \& Pötter GH (2015) Necessidades térmicas de videiras na região da Campanha do Rio Grande do Sul-Brasil. Ciência Rural, 45:626-632.

Regina MA, Mota RV, Favero AC, Shiga TM, Silva LHJ, Souza WC, Novelli FAD \& Souza CR (2011) Caracterização físicoquímica de uvas viníferas cultivadas em regime de dupla poda no nordeste do estado de São Paulo. Revista Brasileira de Viticultura e Enologia, 3:84-92.

Regina MA, Carmo EL, Fonseca AR, Purgatto E, Shiga TM, Lajolo FM, Ribeiro AP \& Mota RV (2010) Influência da altitude na qualidade das uvas 'Chardonnay' e 'Pinot Noir' em Minas Gerais. Revista Brasileira de Fruticultura, 32:143-150.

Ricce WS, Caramori PH \& Roberto SR (2013) Potencial climático para a produção de uvas em sistema de dupla poda anual no Estado do Paraná. Bragantia, 72:408-415.

Rizzon LA \& Miele A (2002) Avaliação da cv. Cabernet Sauvignon para elaboração de vinho. Ciência e Tecnologia de Alimentos, 22:192-198.

Roberto SR, Sato AJ, Brenner EA, Jubileu BS, Santos CE \& Genta W (2005) Caracterização da fenologia e exigência térmica (graus-dia) para a uva 'Cabernet Sauvignon' em zona subtropical. Acta Scientiarum Agronomy, 27:183-187.

Santibáñez F, Sierra H \& Santibáñez P (2014) Degree day model of table grape (Vitis vinifera L.) phenology in mediterranean temperate climates. International Journal of Environmental Science and Technology, 3:10-22.

Santos HP, Amarante CVT, Steffens CA, Ventura DW \& Miqueloto A (2010) Qualidade da uva 'Cabernet Sauvignon' submetida ao raleio de cachos no sistema de condução latada. Revista de Ciências Agroveterinárias, 9:160-168.

Sato AJ, Silva BJ, Santos CE, Bertolucci R, Guiraud MC, Fonseca ICB \& Roberto SR (2009) Evolução da maturação e características físico-químicas de uvas da cultivar Isabel sobre diferentes porta-enxertos na Região Norte do Paraná. Semina: Ciências Agrárias, 30:11-20.

Sato AJ, Jubileu BS, Assis AM \& Roberto SR (2011) Fenologia, produção e composição do mosto da 'Cabernet Sauvignon' e 'Tannat' em clima subtropical. Revista Brasileira de Fruticultura, 33:491-499.

Silva MJR, Tecchio MA, Moura MF, Brunelli LT, Imaizumi VM \& Venturini filho WG (2015) Composição físico-química do mosto e do vinho branco de cultivares de videiras em resposta a porta enxertos (2015) Pesquisa Agropecuária Brasileira, 50:1105-1113.

Silvestre MR (2016) Técnicas estatísticas utilizadas em climatologia geográfica: diagnóstico e propostas. Tese de Doutorado. Universidade Estadual Paulista 'Júlio de Mesquita Filho', Presidente Prudente. 409p.

Sousa JSI \& Martins FP (2002) Viticultura brasileira: principais variedades e suas características. Piracicaba, FEALQ. 368p.

Tonietto J, Vianello RL \& Regina MA (2006) Caracterização macroclimática e potencial enológico de diferentes regiões com vocação vitícola em Minas Gerais. Informe Agropecuário, $27: 32-55$. 